\title{
Proses Pengiriman Paket IP Menggunakan All Optical Label Swapping (AOLS)
}

\author{
Herlinawati $^{1}$, Umi Murdhika $^{1}$, Eka Riyadi $^{2}$ \\ 1.Staf Pengajar Jurusan Teknik Elektro Fakultas Teknik Universitas Lampung \\ 2. Alumni Jurusan Teknik Elektro Fakultas Teknik Universitas Lampung \\ Jl. Prof. Dr. S.Brodjonegoro No. 1 Bandar Lampung \\ herlinawati@unila.ac.id
}

\begin{abstract}
Abstrak - Pengiriman paket IP ke dalam jaringan WDM akan mengalami proses enkapsulasi pada Data Link Layer dengan menambahkan overhead pada paket. Paket IP melalui Gigabit Ethernet mempunyai overhead yang lebih sedikit dibandingkan dengan ATM. Penggunaan teknologi All Optical Label Swapping (AOLS) untuk mengirimkan paket IP ke dalam jaringan WDM dengan menggunakan label swapping akan menambahkan label optik pada paket. Pada AOLS proses penentuan routing dilakukan dengan memproses label optik saja, sedangkan payload data di-delay guna memberikan waktu untuk memproses label optik. Selama proses itu payload data tetap berada pada domain optik.
\end{abstract}

Kata kunci: ATM, Gigabit Ethernet, AOLS, label optik.

\begin{abstract}
Transmission IP packet into WDM network will experience of encapsulation process at Data Link Layer with adding overhead to packet. IP packet through Gigabit Ethernet have more less overhead than ATM. The usage of All Optical Label Swapping (AOLS) technology for transmitting IP packet into WDM network with using label swapping will add optical label to packet. At AOLS, process routing decision is to be done with only processing the optic label. During that process data payload constantly within optic domain.
\end{abstract}

Key word : ATM, Gigabit Ethernet, AOLS, optic label.

\section{A. Pendahuluan}

Pertumbuhan trafik data berbasis paket IP yang semakin pesat, membutuhkan teknologi yang mampu mengakomodasi peningkatan permintaan akan bandwidth yang besar untuk mentransmisikan paket IP dalam jaringan. Teknologi yang

Naskah ini diterima pada tanggal 20 Juni 2008, direvisi pada tanggal 20 Juli 2008 dan disetujui untuk diterbitkan pada tanggal 1 Agustus 2008 menjanjikan untuk memenuhi permintaan bandwidth yang tinggi adalah jaringan optik dengan wavelength division multiplexing (WDM). Teknologi yang digunakan dalam routing paket di dalam node jaringan optik adalah proses optikelektronik-optik (O-E-O) dimana paket optik akan diproses secara elektronik untuk menentukan proses routing dan selanjutnya akan dikonversi kembali menjadi paket optik. Hal ini akan menimbulkan bottleneck di dalam jaringan dimana terdapat perbedaan yang besar antara kapasitas pengiriman paket pada jaringan optik dengan kapasitas pemrosesan paket pada node jaringan untuk keperluan routing yang dilakukan secara elektronik.

\section{All Optical Label Swapping (AOLS)} digunakan untuk mengatasi masalah perbedaan antara kapasitas transmisi serat optik dengan kapasitas forwarding router. AOLS menerapkan proses optik-optikoptik (O-O-O) dalam pengiriman paket dalam jaringan yang akan mengurangi proses elektronik dalam routing paket.

\section{B. Teori Dasar}

Internet Protocol (IP)

Protokol IP merupakan inti dari protokol TCP/IP. Seluruh data yang berasal dari protokol pada layer di atas IP harus dilewatkan dan diolah oleh protokol IP serta dipancarkan sebagai paket IP agar sampai ke tujuan. Dalam melakukan pengiriman data, IP memiliki sifat sebagai berikut :

a.Unreliable atau ketidakandalan; dimana protokol IP tidak menjamin 
datagram yang dikirimkan pasti sampai ke tempat tujuan tetapi hanya melakukan usaha sebaik-baiknya (best effort delivery service), agar paket yang dikirim tersebut sampai ke tujuan.

b.Connectionless; dimana dalam pengiriman paket dari tempat asal ke tujuan, pihak pengirim dan penerima paket IP sama sekali tidak mengadakan perjanjian terlebih dahulu.

c.Datagram delivery service; dimana setiap paket data yang dikirim berdiri sendiri terhadap paket data yang lain. Akibatnya jalur yang ditempuh oleh masing-masing paket data IP ke tujuannya bisa jadi berbeda satu dengan lainnya sehingga kedatangan paket tidak berurutan.

\section{Asynchronous Transfer mode (ATM)}

ATM adalah standar ITU-T untuk cell relay dimana informasi seperti voice, video, serta data dikirimkan dalam sel kecil yang berukuran tetap

Karakteristik Umum ATM sebagai berikut:

- beroperasi pada mode connectionoriented.

- panjang filed informasi dalam satu sel relatif kecil

Pada ATM, seluruh informasi yang akan ditransfer akan dibagi menjadi slot-slot dengan ukuran tetap yang disebut sel. Ukuran sel ATM adalah 53 byte $(1$ byte $=$ 8 Bit) yang terdiri dari 48 byte untuk field informasi dan 5 byte untuk header, seperti terlihat pada gambar 1 .

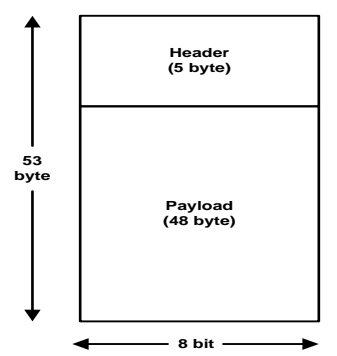

Gambar 1. Format Dasar Sel ATM
Model Referensi ATM dengan dua layer terbawah dari model OSI ditunjukan pada gambar 2.

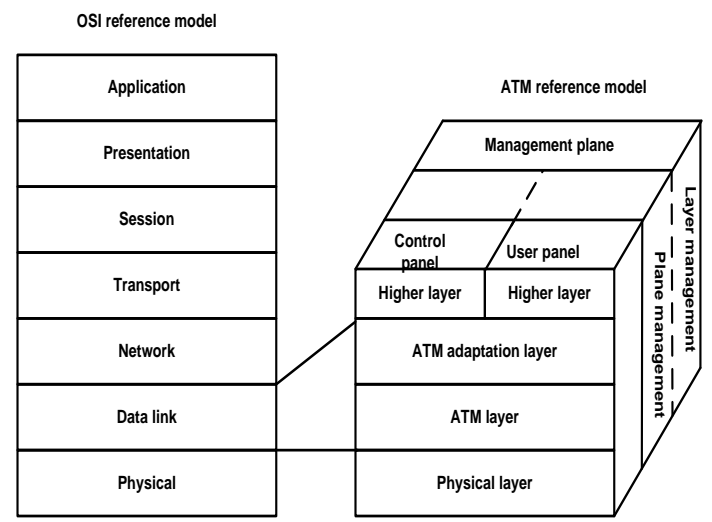

Gambar 2. Model referensi ATM dengan dua layer terbawah dari model OSI.

Model referensi ATM terdiri dari 3 plane yaitu :

a. Control plane, yang bertanggung jawab melakukan fungsi manajemen untuk permintaan signalling.

b. User plane, yang bertanggung jawab untuk manajemen dari pengiriman data.

c. Management plane, terdiri dari dua komponen yaitu:

- Layer management yang mengatur fungsi-fungsi layer yang spesifik seperti pendeteksian kesalahan.

- Plane management yang mengatur dan mengkoordinasikan antara seluruh plane yang ada.

\section{Gigabit Ethernet}

Gigabit Ethernet adalah standar IEEE $802.3 \mathrm{z}$ yang merupakan pengembangan dari 10 dan 100 Mbps Ethernet, dengan frame dari 64 sampai 1500 byte.

Gigabit Ethernet merepresentasikan peningkatan data rate dan pengurangan waktu yang dibutuhkan untuk mentransmisikan frame dengan faktor 10 . Hal ini dicapai dengan pengurangan dari diameter jaringan. Gambar 3 menunjukkan format frame Gigabit Ethernet dengan carrier extention. 


\begin{tabular}{c|c|c|c|c|c|c|c|c|c|}
\hline PRE & SFD & DA & SA & Lengthtype & Data & Pad & FCS & $\begin{array}{c}\text { Carrier } \\
\text { extension }\end{array}$ \\
\hline 7 & 1 & 6 & 6 & 2 & $46-1500 \longrightarrow 4$ & $0-448$
\end{tabular}

Gambar 3. Format frame Gigabit Ethernet dengan carrier extension (dalam byte).

Gigabit Ethernet memiliki kelebihan "frame bursting", yang membolehkan Gigabit Ethernet untuk mentransmisikan beberapa frame pendek. Saat station telah diperbolehkan mengirimkan frame, yang mungkin memerlukan atau tidak memerlukan carrier extension, maka "burst timer" dimulai. Jika frame pertama sukses ditransmisikan, kemudian station pengirim mempunyai pilihan untuk mentransmisikan frame tambahan dimana dalam kondisi ada frame lain yang sudah antri dan burst timer belum berakhir. Awal dari frame terakhir dalam burst harus datang sebelum burst timer berakhir, tetapi pentransmisian tersebut bisa diperpanjang melebihi batas dari burst timer. Lama maksimun dari satu kali pentransmisian dapat berupa penjumlahan dari panjang burst dan ukuran maksimum frame, yang bisa mencapai 6 panjang ukuran maksimum frame. 96 bit interframe gap ditransmisikan berturut-turut pada setiap frame dalam burst.

\section{Wavelength Division Multiplexing (WDM)}

Wavelength division multiplexing (WDM) merupakan teknologi yang memultipleks beberapa sinyal pembawa optik pada sebuah serat optik tunggal dengan menggunakan panjang gelombang berbeda dari cahaya laser untuk membawa sinyal yang berbeda

Teknologi WDM menggunakan dua widely space wavelength di dalam wilayah 1310 $\mathrm{nm}$ dan $850 \mathrm{~nm}$, diperlihatkan pada gambar 4

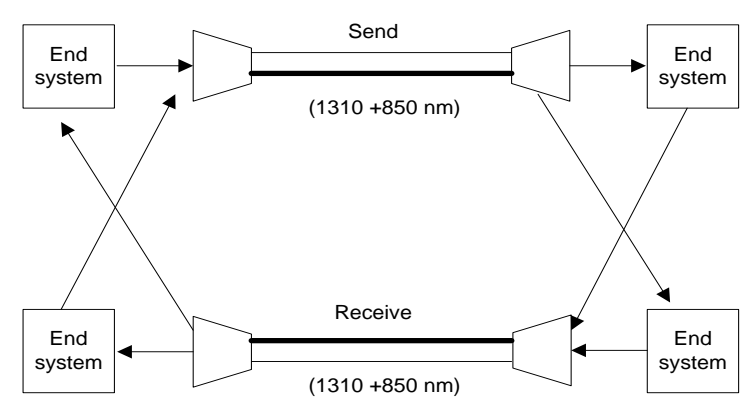

Gambar 4. WDM dengan dua kanal.

Kemajuan dari teknologi WDM dapat dilihat sebagai suatu peningkatan pada jumlah panjang gelombang yang diikuti oleh suatu penurunan pengaturan jarak antar panjang gelombang,ditunjukkan pada gambar 5.

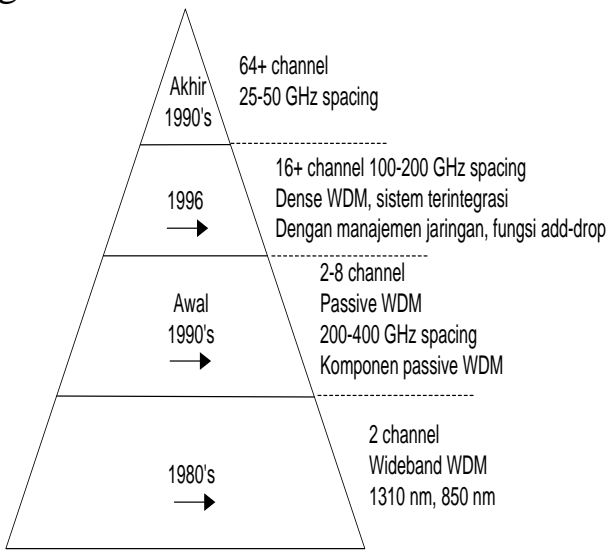

Gambar 5. Evolusi dari teknologi WDM.

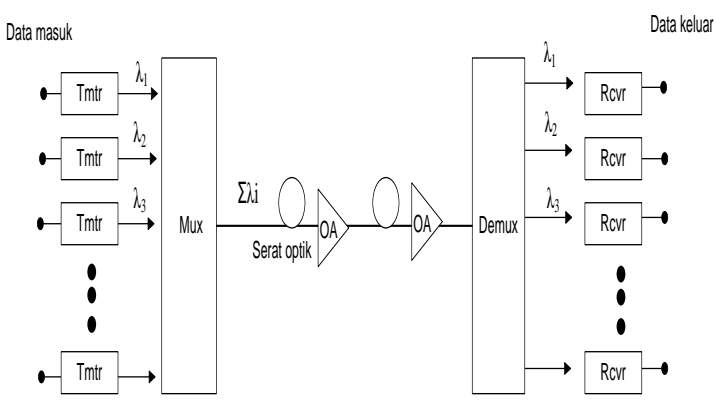

Gambar 6. Dasar konfigurasi sistem WDM.

Gambar 6 menjelaskan sistem dasar WDM untuk aplikasi pada transmisi dari titik ke titik berkapasitas besar. Sinyal untuk panjang gelombang yang berbeda telah dimultipleks secara optik sehingga $\mathrm{N}$ panjang gelombang ditransmisikan secara simultan pada jaringan serat optik. Optical amplifier digunakan untuk memperbaiki 
kerugian yang terjadi dalam pentransmisian melalui serat optik seperti attenuation dan loss komponen. Pada receiver sinyal didemultipleks dan dideteksi oleh opto-electronic receivers.

\section{Sistem point-to-point WDM}

Gambar 7 menunjukan sistem transmisi WDM point-to-point empat kanal dengan amplifier.

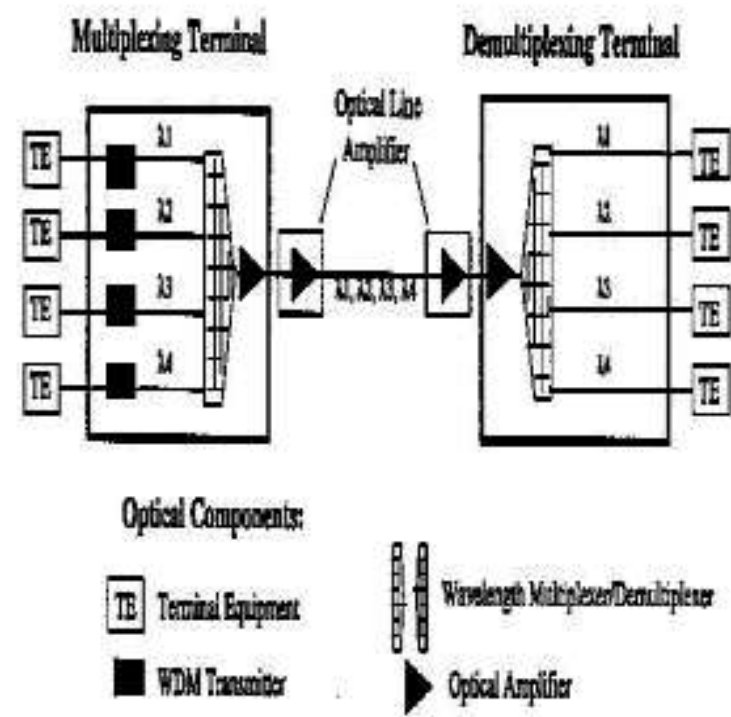

Gambar 7. Sistem transmisi WDM pointto-point empat kanal dengan amplifier.

\section{Wavelength Add/Drop Multiplexer (WADM)}

Pada gambar 8. WADM menggunakan topologi ring dalam arsitektur jaringannya.

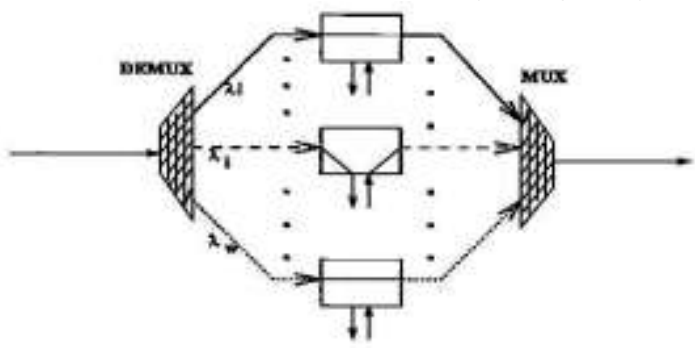

Gambar 8. Wavelength add/drop multiplexer (WADM).

WADM terdiri dari demux, diikuti oleh $2 \mathrm{x}$ 2 switch (satu switch untuk setiap panjang gelombang atau wavelength) dan terakhir mux. Jika seluruh dari 2 x 2 switch dalam kondisi bar maka semua panjang gelombang mengalir melewati WADM Jika salah satu dari 2 x 2 switch dikonfigurasi dalam keadaan cross menggunakan kontrol elektronik, sinyal pada panjang gelombang tersebut akan di dropped secara lokal, dan data stream baru dapat di added pada panjang gelombang yang sama dalam lokasi WADM ini. Fungsi dari add/drop multiplexing dapat diganti untuk implementasi dari optical add/drop multiplexer (OADM)

\section{Optical Cross-connect (OXC)}

Infrastruktur dari jaringan optik yang ada sekarang menggunakan topologi mesh dengan optical cross-connect (OXC).

Arsitektur jaringan optik menggunakan OXC dapat berupa opaque atau transparent. Gambar 9 menunjukan 3 arsitektur node yang berbeda dari jaringan optik menggunakan OXC

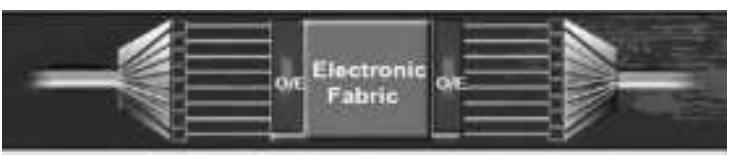

9(a) Jaringan opaque -opaque switch.

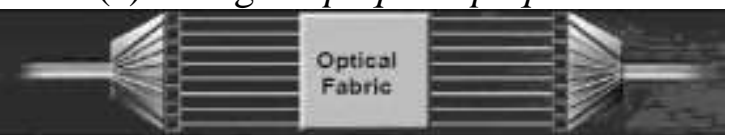

9(b) Jaringan opaque -transparent switch.

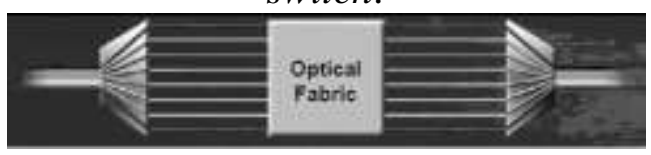

9(c) Jaringan transparent -transparent switch.

Gambar 9. Arsitektur node untuk jaringan mesh optik menggunakan $\mathrm{OXC}$.

Arsitektur 9(a) menunjukkan arsitektur jaringan opaque, dimana sinyal optik mengalami konversi optik-elektronik-optik (O-E-O) dengan opaque (O-E-O) switch. Arsitektur 9(b) menunjukkan transparent optik-optik-optik (O-O-O) switch antara sistem WDM dengan transponder yang 
berupa O-E-O switch untuk drop trafik. Arsitektur ini juga berupa jaringan opaque, dimana sinyal optik mengalami konversi O-E-O pada WDM transponder.

Arsitektur 9(c) menunjukkan topologi jaringan transparent secara menyeluruh meliputi transparent optical switch dan sistem WDM yang tidak mengandung transponder.

\section{All Optical Label Swapping (AOLS)}

AOLS mengimplementasikan fungsi routing dan forwarding paket per paket secara langsung dalam layer optik. AOLS mengarah pada konsep penggunaan label optik untuk mengenkapsulasi paket IP dalam layer optik. Format label optik dipilih untuk pasangan terbaik dari teknologi routing dan forwarding optik

AOLS mempunyai kemampuan untuk mengirimkan langsung paket melalui jaringan optik tanpa harus melewatkan paket kedalam proses elektronik pada saat penentuan routing dibutuhkan. Jaringan inti paket optik dari AOLS digambarkan pada gambar 10. Paket IP masuk ke dalam jaringan inti pada suatu ingress router dan melakukan perjalanan ke berbagai titik cabang melalui inti, keluar pada suatu egress router. Paket ditangani di dalam jaringan oleh router inti AOLS atau subnet AOLS. Pada saat paket IP masuk ke dalam jaringan melalui ingress, paket IP dibungkus dengan label optik kemudian ditransmisikan kembali pada suatu panjang gelombang yang baru.

Label optik dan panjang gelombang yang baru ditentukan dengan membaca header paket IP dan menggunakan informasi yang disimpan di dalam local table. Setelah berada di jaringan, hanya label optik yang digunakan untuk membuat keputusan routing dan panjang gelombang digunakan untuk forwarding paket. Pada saat sampai di AOLS core router label dibaca dan secara optik dihapus, kemudian label baru ditambahkan pada paket dan paket yang sudah diberi label optik baru dikonversikan kedalam panjang gelombang yang baru menggunakan wavelength converter. Selama proses ini, isi paket tidak dikirimkan ke proses elektronik.

Gambar 11 melukiskan elemen fisik jaringan yang dihubungkan dengan hubungan serat optik dan hirarki dari routing dan forwarding paket. Paket IP dihasilkan pada layer routing elektronik dan diproses pada layer adaptasi yang membungkus paket IP dengan label optik tanpa memodifikasi struktur asli dari paket. Layer adaptasi juga mengubah paket dan label ke suatu panjang gelombang baru yang ditentukan oleh tabel routing. Layer multiplexing optik memultipleks paketpaket yang sudah diberi label ke suatu medium serat optik bersama.

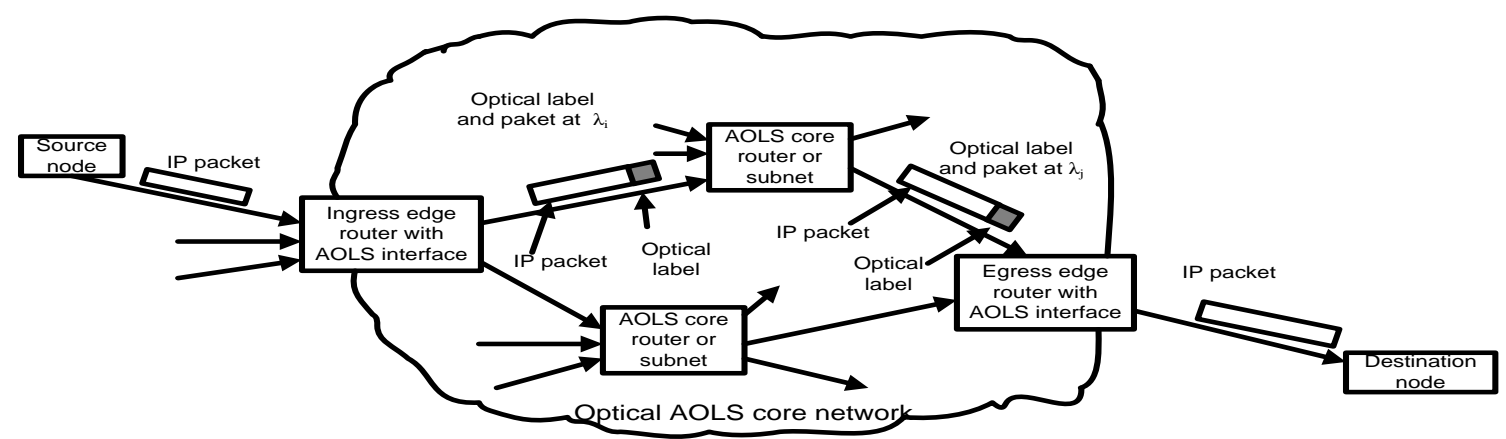

Gambar 10. Optical label swapping dengan konversi di dalam jaringan inti optik menggunakan edge dan inti WDM IP router. 


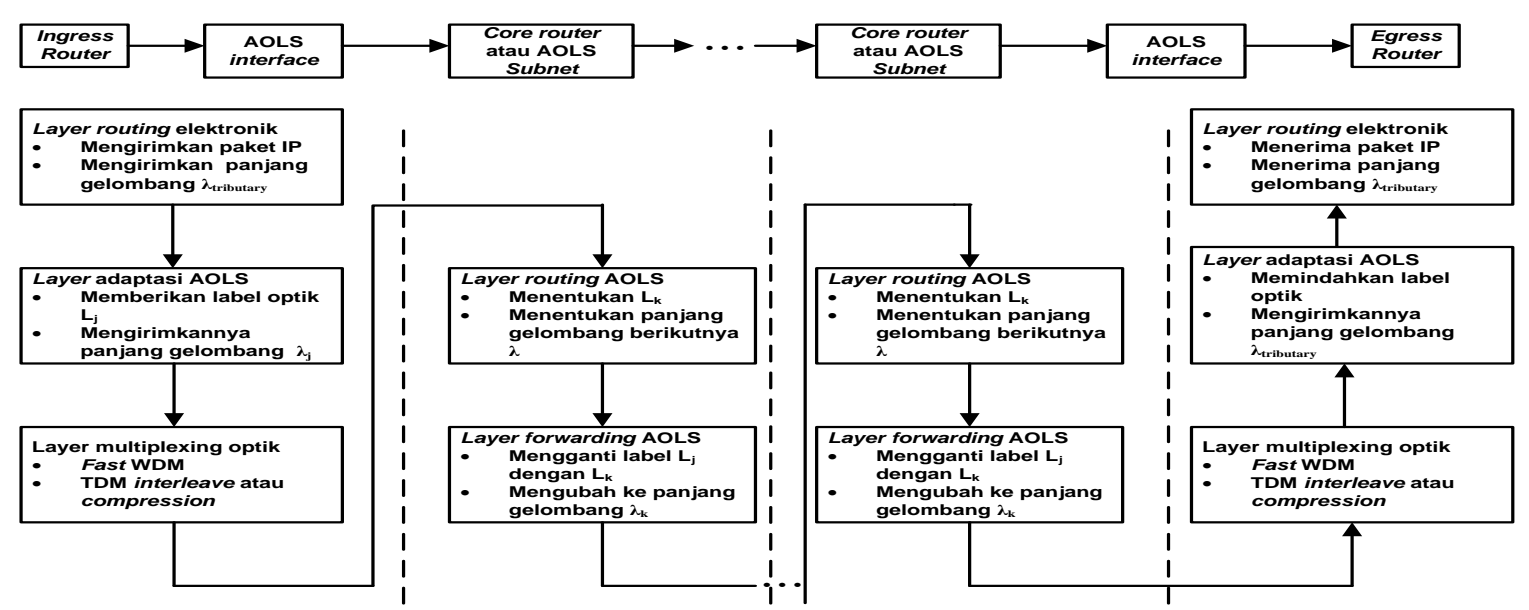

Gambar 11. Hirarki dari routing dan forwarding dan diagram hubungan antar elemen untuk jaringan AOLS.

Saat berada di dalam jaringan inti, router inti atau subnet melaksanakan fungsi routing dan forwarding. Fungsi routing menentukan label dan panjang gelombang baru dari tabel routing. Tabel routing (pada egress dan router inti) dihasilkan dengan mengkonversi alamat IP ke dalam pasangan label dan panjang gelombang dan mendistribusikannya ke dalam jaringan. Fungsi forwarding meliputi penukaran label asli dengan label baru dan secara fisik mengkonversi paket yang telah diberi label ke dalam panjang gelombang yang baru. Proses sebaliknya dari demultiplexing optik, adaptasi, dan routing elektronik dilaksanakan pada egress.

\section{Teknik Pengkodean Label Optik} Metode dari pengkodean label ke dalam paket berhubungan dengan efisiensi bandwidth kanal, kualitas transmisi dari paket dan label, dan metode terbaik untuk mengkonversi panjang gelombang paket dan penukaran label secara optik. Dua pendekatan untuk pengkodean label secara optik yaitu label serial dan label subscriber multiplex optik yang digambarkan pada gambar 12

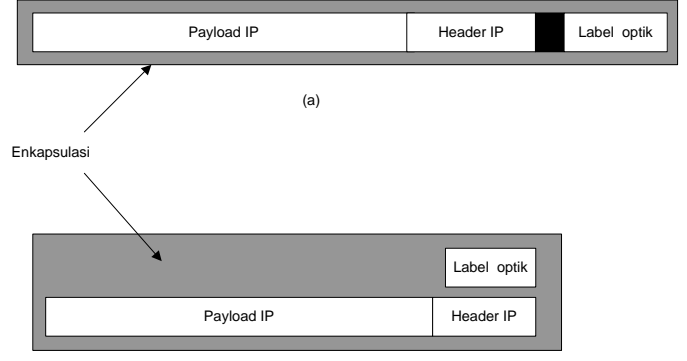

(b)

Gambar 12. Teknik pengkodean label optik (a) label serial dan (b) label subscriber multiplex.

Dengan pengkodean label serial bit rate yang tetap dimultipleks pada bagian header paket IP yang keduanya dipisahkan oleh optical guard band (OGB) seperti yang digambarkan pada gambar 12(a). OGB digunakan untuk memfasilitasi pemindahan dan pengisian kembali label tanpa buffering paket yang statik dan untuk mengakomodasi waktu switching yang terbatas dari switching optik dan pengkonversian panjang gelombang. Bit serial label di-encode-kan pada panjang gelombang yang sama seperti paket IP dan di-encode-kan sebagai sinyal baseband. Untuk label subcarrier multiplex optik suatu label baseband dimodulasikan kedalam RF subcarrier dan kemudian dimultipleks dengan paket IP pada panjang gelombang yang sama seperti yang terlihat pada gambar 12(b). OGB tidak diperlukan 
didalam kasus subcarrier dimana label ditransmisikan secara paralel bersama paket. Tranparansi paket direalisasikan dengan mengeset bit rate label yang tetap dan format modulasi yang berdiri sendiri dari bit rate paket. Pemilihan bit rate label dilakukan oleh kombinasi dari beberapa faktor, termasuk kecepatan dari pemulihan mode burst elektronik dan durasi dari label yang berhubungan dengan paket terpendek pada bit rate dari paket yang tercepat.

Label subcarrier dapat dipindahkan dan ditempatkan kembali secara lebih asynchronous dengan kemungkinan paket mengalami dispersi termasuk fading .

\section{Fungsi Dan Bangunan Blok AOLS} Perbaikan label, label swapping dan forwarding paket adalah fungsi dasar yang ditangani oleh AOLS, seperti yang digambarkan pada gambar 13.

Didalam core router atau subnet AOLS modul perbaikan label mode burst digunakan untuk memperbaiki clock label dan data untuk pemrosesan dalam routing sirkuit elektronik tanpa secara signifikan mengganggu keluar masuknya paket data optik. Sirkuit routing memetakan label dan panjang gelombang yang masuk kedalam label dan panjang gelombang yang baru berdasarkan dari tabel routing. Proses penghapusan label dibangun di dalam stage ini tergantung dari implementasi teknologinya. Stage kedua melaksanakan penghapusan label (jika tidak dilaksanakan pada stage pertama), pengkonversian panjang gelombang dan label rewriting menggunakan wavelength converter atau kombinasi dari wavelength converter dan filter optik. Fiber optik delay mengikuti stage perbaikan label untuk mencocokan delay proses routing dengan kedatangan paket pada stage optik kedua. Suatu edge router menggunakan sedikit modifikasi dari stage pertama untuk mendeteksi header paket IP dengan gangguan yang minimum pada paket. Stage kedua melaksanakan proses yang sama dari wavelength converter dan label rewriting seperti pada core router.

\section{C.Metode Penelitian}

Penelitian ini dilakukan secara sistematis, sebagai berikut :

1. Melakukan proses enkapsulasi paket IP melalui ATM.

2. Melakukan tentang proses enkapsulasi paket IP melalui Gigabit Ethernet.

3. Menghitung jumlah overhead yang dialami paket IP pada proses enkapsulasi paket IP melalui ATM.

4. Menghitung jumlah overhead yang dialami paket IP pada proses enkapsulasi paket IP melalui Gigabit Ethernet.

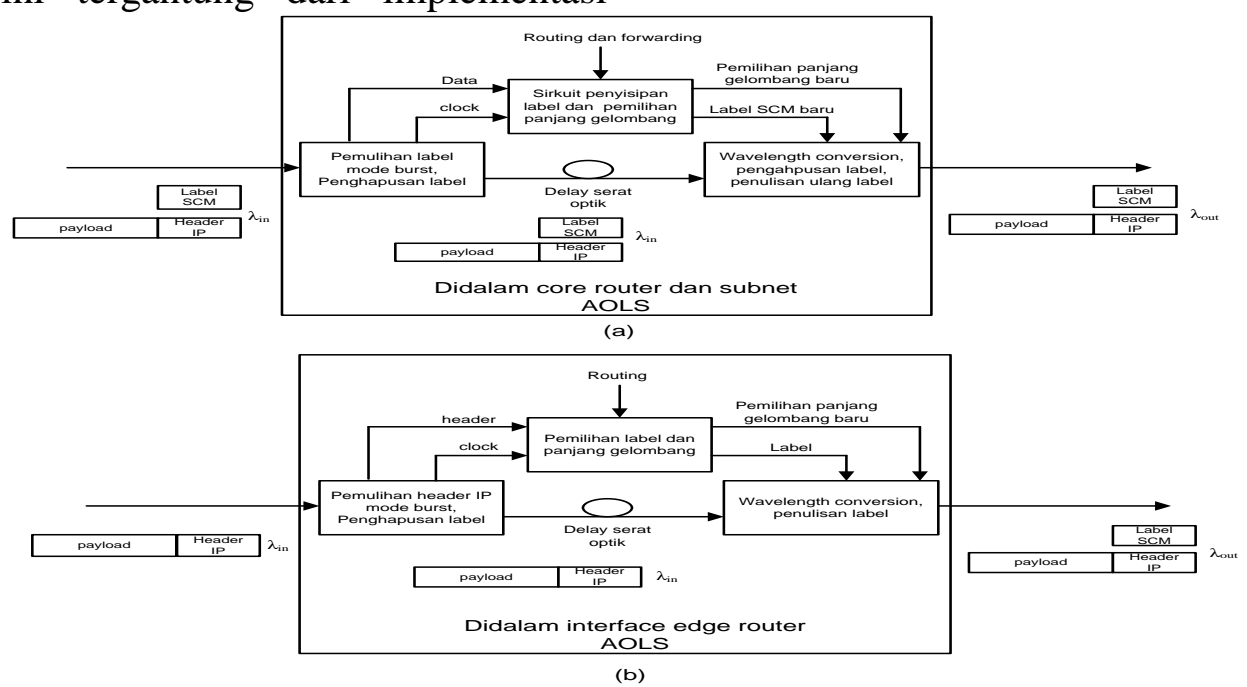

Gambar 13. Bangunan blok untuk AOLS (a) core router atau subnet dan (b) edge router. 
5. Membandingkan jumlah overhead yang dialami paket IP antara melalui ATM dan Gigabit Ethernet.

6. Melakukan proses routing yang dialami paket IP melalui jaringan opaque.

7. Melakukan proses routing yang dialami paket IP melalui jaringan AOLS.

8. Membandingkan proses routing yang dialami paket IP antara jaringan opaque dengan AOLS.

\section{Hasil dan Pembahasan}

\section{Paket IP melewati ATM}

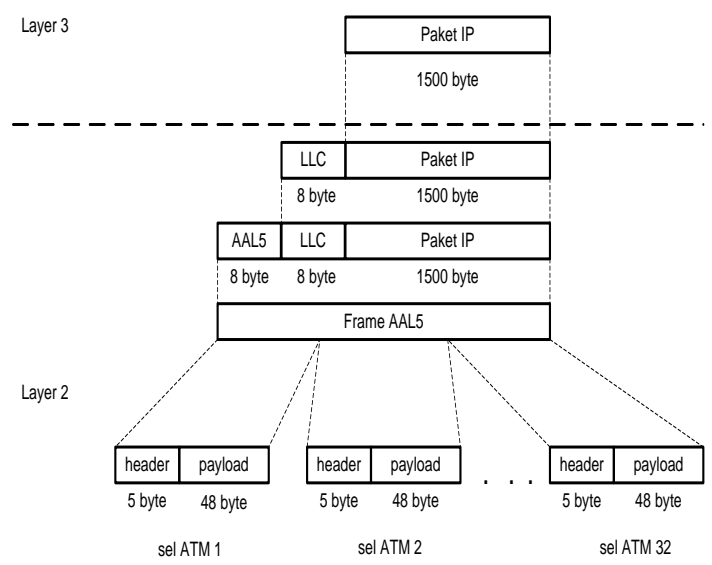

Gambar 14. Enkapsulasi paket IP kedalam sel ATM.

Pada saat paket IP melewati ATM, paket akan mendapat tambahan 8 byte header Logical Link Layer (LLC) yang berisikan ID protokol yang lebih tinggi dan juga LLC menyediakan interface ke dalam network layer. Paket diteruskan ke ATM Adaptation Layer 5 (AAL5), dan ditambahkan overhead 8 byte untuk membentuk frame AAL5. Layer AAL5 kemudian memecah frame tersebut menjadi sel-sel ATM dengan masing-masing sel berukuran 48 byte ditambah 5 byte header. Kemudian paket dikirimkan ke ATM layer yang berfungsi untuk sel multiplexing dan demultiplexing serta mengirimkan sel ke dalam ATM network. ATM layer menggunakan informasi Virtual Path Identifier (VPI) dan Virtual Channel Identifier (VCI) dalam header dari setiap sel ATM. ATM Network merupakan Connection-Oriented, dimana Virtual Channel (VC) harus dibangun melintasi ATM Network sebelum terjadi pengiriman data.

Pada ATM, paket IP sebesar 1500 byte, akan ditambahkan 8 byte header LLC. Kemudian ditambahkan lagi 8 byte header ATM AAL5 serta 20 byte pad untuk membuat panjang paket menjadi kelipatan 48 byte. Jumlah total frame AAL5 menjadi 1536 byte. Setelah itu frame AAL5 itu dipecah menjadi segmen-segmen yang berukuran 48 byte sehingga terdiri atas 32 sel ATM. Setiap sel ATM terdiri dari 5 byte header dan 48 byte payload. Total jumlah byte adalah 1696 byte.

Dengan total tambahan overhead sebesar 196 byte pada paket 1500 byte maka :

Besar overhead yang dialami paket IP (\%)

$$
=\frac{196}{1500} \times 100 \%=13,07 \% \text {. }
$$

\section{Paket IP Melewati Gigabit Ethernet.}

Pada saat paket IP melewati Gigabit Ethernet, paket IP tersebut akan dikirimkan ke dalam LLC dan paket tersebut akan ditambahkan header LLC. Byte LLC akan dimasukan dalam bidang data. Kemudian paket dan byte LLC akan dibungkus ke dalam payload untuk membentuk frame MAC Gigabit Ethernet. Enkapsulasi paket IP ke dalam Frame Gigabit Ethernet dapat dilihat pada gambar 15.

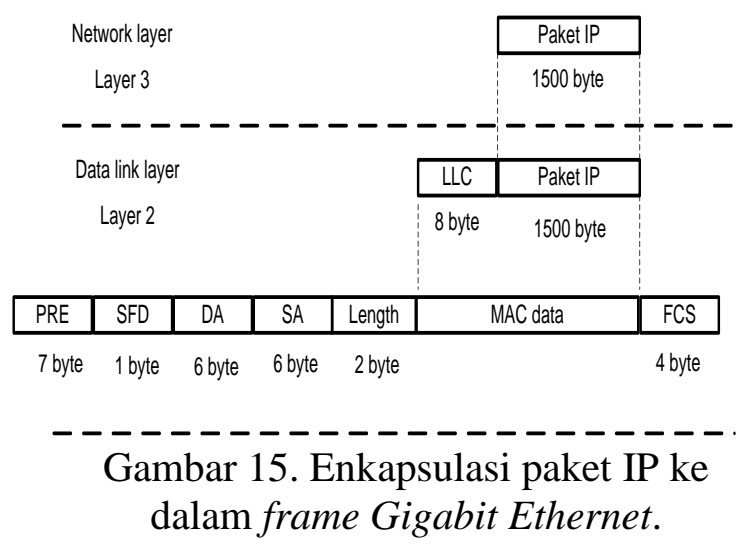


Setelah itu dengan menggunakan versi 1000Base-X, frame Gigabit Ethernet tersebut di-encode ke dalam sinyal pembawa optik menggunakan $8 \mathrm{~B} / 10 \mathrm{~B}$ encoding. Dalam 8B/10B encoding setiap byte atau 8 bit data dipetakan dalam 10 bit group kode untuk transmisi serial bit. Dengan 1000Base-X keluarannya sebesar $1 \mathrm{Gbps}$ dan line rate-nya sebesar 1,25 Gbps. Jadi keluaran dari Gigabit Ethernet ini adalah berupa paket IP yang sudah di dalam frame Gigabit Ethernet dan telah diencode menjadi sinyal optik.

Pada Gigabit Ethernet, paket IP sebesar 1500 byte akan ditambahkan 8 byte header LLC. Kemudian ditambahkan 26 byte frame Gigabit Ethernet sehingga totalnya menjadi 1534 byte

Dengan total tambahan overhead sebesar 34 byte pada paket 1500 byte maka :

Besar overhead yang dialami paket IP (\%)

$$
=\frac{34}{1500} \times 100 \%=2,27 \% \text {. }
$$

Tabel Perbandingan ATM dan Gigabit Ethernet

\begin{tabular}{|l|l|}
\hline \multicolumn{1}{|c|}{ ATM } & \multicolumn{1}{|c|}{ Gigabit Ethernet } \\
\hline Connection-oriented & Connectionless \\
\hline $\begin{array}{l}\text { Data rate dari 155 } \\
\text { Mbps sampai 2 Gbps }\end{array}$ & Data rate 1,25 Gbps \\
\hline $\begin{array}{l}\text { Jumlah } \text { overhead lebih } \\
\text { besar untuk ukuran } \\
\text { paket 1500 byte }\end{array}$ & $\begin{array}{l}\text { Jumlah } \text { overhead lebih } \\
\text { sedikit untuk ukuran } \\
\text { paket 1500 byte }\end{array}$ \\
\hline $\begin{array}{l}\text { Pengiriman paketnya } \\
\text { berbasis sel berukuran } \\
\text { tetap }\end{array}$ & $\begin{array}{l}\text { Pengiriman paket } \\
\text { berbasis frame }\end{array}$ \\
\hline $\begin{array}{l}\text { Digunakan untuk SDH } \\
\text { atau SONET }\end{array}$ & $\begin{array}{l}\text { Digunakan umum } \\
\text { untuk LAN }\end{array}$ \\
\hline
\end{tabular}

\section{Paket IP Melewati Jaringan Opaque}

Infrastruktur jaringan optik yang ada sekarang ini sebagian besar menggunakan OXC yang berupa jaringan opaque dengan opaque switch. Gambar 16 mengilustrasikan bagaimana bentuk jaringan metro opaque.

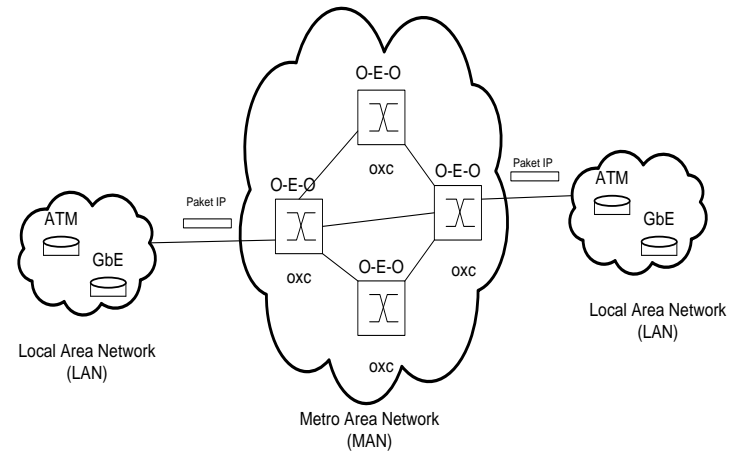

Gambar 16. Arsitektur jaringan metro opaque.

Jaringan opaque menggunakan opaque switch berarti bahwa paket IP dalam pentransmisiannya akan mengalami konversi O-E-O. Proses yang terjadi pada opaque switch terlihat pada gambar 17.

Sinyal optik dilewatkan pada O-E-O transponder, yang biasanya mengubah sinyal optik pada region $1310 \mathrm{~nm}$. Sinyal Optik tersebut kemudian diubah ke dalam bentuk elektrik dan didemultipleks ke dalam sinyal STS-1. Sinyal optik dihubungkan silang menggunakan sebuah $n$ $x$ STS-1 matrik dan dimultipleks ke rate SONET yang lebih tinggi. Kemudian sinyal ditransformasi ke optik, dalam region 1310 $\mathrm{nm}$ dan akhirnya dikonversi ke panjang gelombang keluaran yang sesuai dengan menggunakan O-E-O transponder yang melakukan konversi panjang gelombang statis.

Dari proses tersebut terlihat bahwa untuk proses routing di dalam jaringan opaque, sinyal optik yang membawa paket IP akan dikonversi menjadi elektrik untuk menentukan jalur berikutnya. Setelah ditentukan jalur mana yang akan dilalui maka paket yang sebelumya sudah dikonversi menjadi elektrik, akan diubah lagi menjadi optik untuk proses forwading selanjutnya.

Paket IP Melewati Jaringan All Optical Label Swapping (AOLS) 
AOLS mengimplementasikan fungsi panjang gelombang digunakan untuk routing dan forwarding paket per paket forwarding paket.

secara langsung dalam layer optik. AOLS Pada saat sampai di AOLS core router mengarah pada konsep penggunaan label label dibaca dan secara optik dihapus, optik untuk mengenkapsulasi paket IP kemudian label baru ditambahkan pada dalam layer optik. AOLS memberikan paket dan paket yang sudah diberi label kemampuan fungsional untuk mengirimkan optik baru tersebut dikonversikan ke dalam langsung paket melalui jaringan optik tanpa panjang gelombang yang baru harus melewatkan paket ke dalam proses menggunakan wavelength converter. elektronik pada saat penentuan routing Selama proses ini, isi paket (seperti header dibutuhkan.Suatu jaringan inti paket optik paket IP dan payload) tidak dikirimkan ke dari AOLS digambarkan pada gambar 17. proses elektronik.

Paket IP masuk ke dalam jaringan inti pada suatu ingress router dan melakukan perjalanan ke berbagai titik cabang melalui inti, keluar pada suatu egress router. Paket ditangani di dalam jaringan oleh router inti AOLS atau subnet AOLS. Pada saat paket IP masuk ke dalam jaringan melalui ingress, paket IP tersebut dibungkus dengan label optik dan kemudian ditransmisikan kembali pada suatu panjang gelombang yang baru. Label optik dan panjang gelombang yang baru ditentukan dengan membaca header paket IP dan menggunakan informasi yang disimpan di dalam local table. Setelah berada di jaringan, hanya label optik yang digunakan untuk membuat keputusan routing dan

\section{Konsep Jaringan Lasagne OALS}

Suatu contoh dari jaringan AOLS digambarkan pada gambar 19. Paket IP masuk ke dalam jaringan AOLS melalui ingress node. Paket dengan bit rate rendah $(\sim 10 \mathrm{~Gb} / \mathrm{s})$ dimultipleks dalam daerah optik menjadi bentuk paket dengan bit rate tinggi ( 40-80 Gb/s), dibungkus dengan label optik, ditransmisikan kembali pada panjang gelombang baru jika dibutuhkan. Pada saat berada pada metropolitan area network (MAN) atau wide area network (WAN), hanya label optik yang digunakan untuk menentukan keputusan routing, dimana panjang gelombang digunakan untuk memforward paket dengan bit rate yang tinggi.

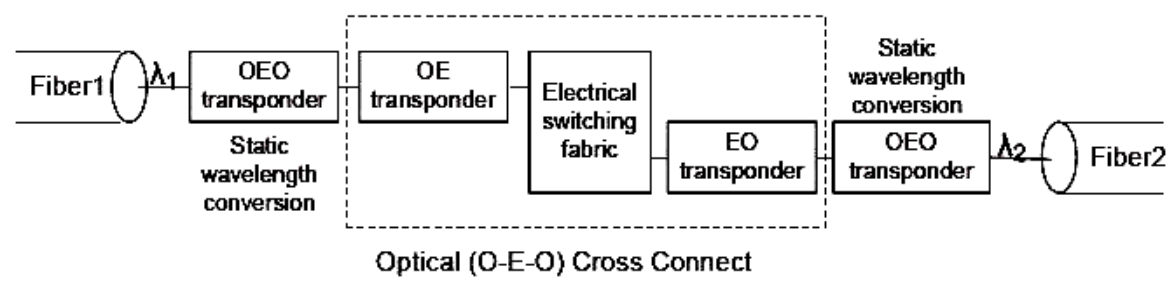

Gambar 17. Proses Elektronik Switching pada opaque switch.

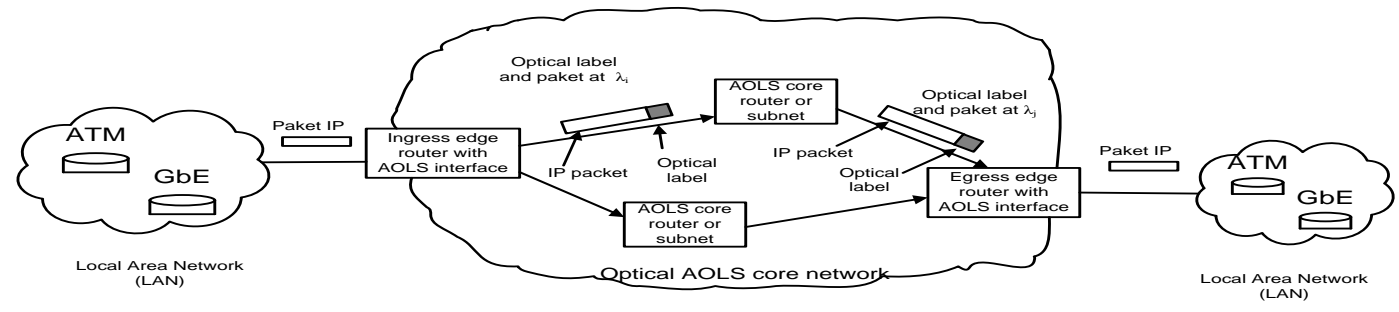

Gambar 18. Arsitektur jaringan All optical label swapping (AOLS). 


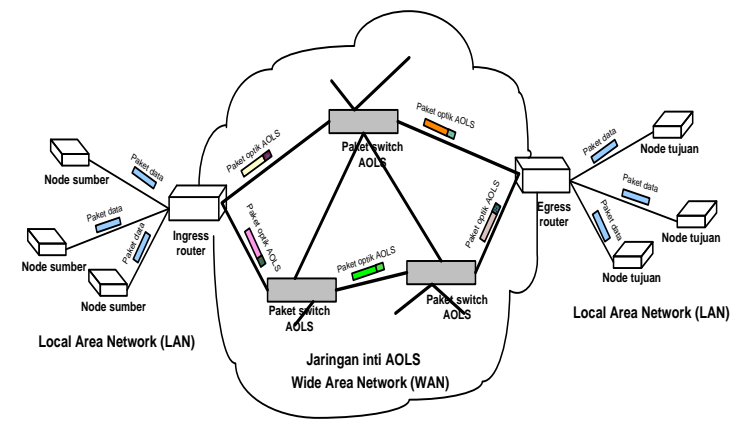

Gambar 19. Skenario jaringan LASAGNE AOLS.

Setiap AOLS router menggunakan isi dari label yang telah diekstrak untuk melaksanakan keputusan forwarding dan mem-forward paket ke arah egress edge router. Optical core router melaksanakan operasi routing dan forwarding bersamaan dengan konversi panjang gelombang dan label swapping. Dalam keseluruhan proses ini, paket dengan bit rate yang tinggi tetap dijaga di dalam daerah optik.

\section{Desain Node}

Kemampuan utama yang dibutuhkan oleh AOLS (pembacaan label, penyisipan label baru, dan routing paket) didasarkan pada penggunaan all-optical logic gates dan flipflop. Pada gambar 20, panjang gelombang yang memasuki node didemultipleks terlebih dahulu dan untuk setiap panjang gelombang blok AOLS diimplementasikan. Pada gambar 21 saat paket memasuki modul AOLS, label optik (10 Gbps) dipisahkan dari paket payload (40 Gbps) oleh sirkuit pemisah label dan payload. Setelah dipisahkan payload paket secara optik diperlambat oleh optical delay line (ODL) guna memberikan waktu untuk pemrosesan dari label. ODL berfungsi sebagai buffer optik untuk payload paket. Hasil ekstraksi label dimasukan ke dalam bank dari optic correlators yang didasarkan pada all-optical logic XOR gates (AOLXGs), dimana perbandingan antara label dan set dari alamat lokal dilakukan.

Alamat lokal ini dihasilkan menggunakan optical delay line (ODL). Suatu ODL terdiri atas satu set dari fiber delay line yang terinkoneksi, couplers, dan spliter yang menghasilkan urutan bit keluaran dari satu pulsa. Setelah membandingkan, pulsa dengan intensitas yang tinggi akan muncul pada keluaran dari XOR dengan alamat yang cocok. Pulsa ini memberi masukan pada blok kontrol yang mengarahkan wavelength converter. Blok kontrol ini disusun dari all-optical flip-flop (AOFF).

Bergantung pada kecocokan alamat (keluaran pulsa correlator), flip-flop yang sesuai akan memancarkan sinyal continous wave (cw) pada panjang gelombang tertentu. Sementara itu, label baru dihasilkan di dalam ODL yang sesuai. Label baru disisipkan di depan payload dan keduanya (payload dan label baru) kemudian dikonversi menjadi panjang gelombang yang dihasilkan oleh flip-flop.

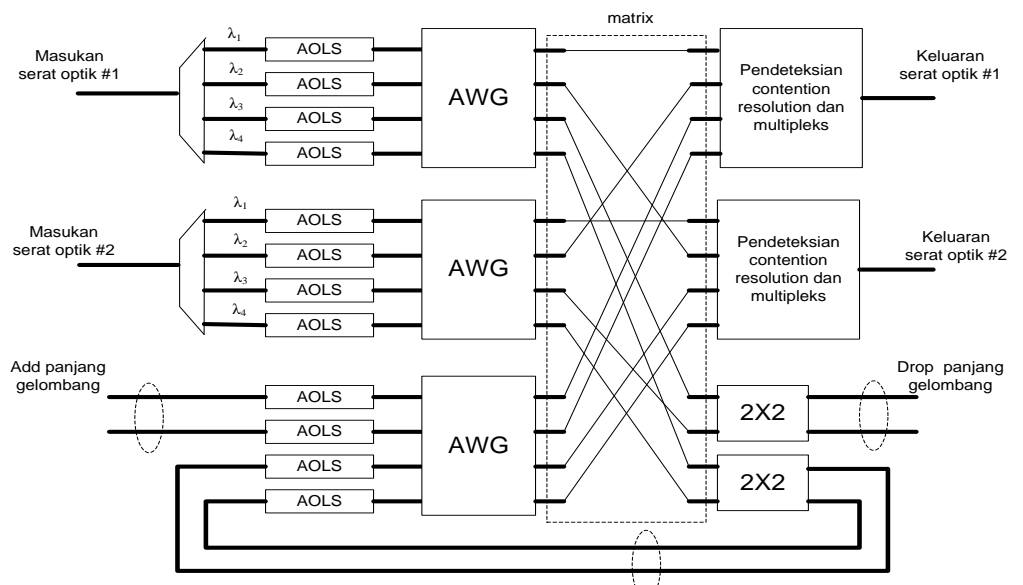

Gambar 20. Arsitektur yang diusulkan untuk routing photonic. 


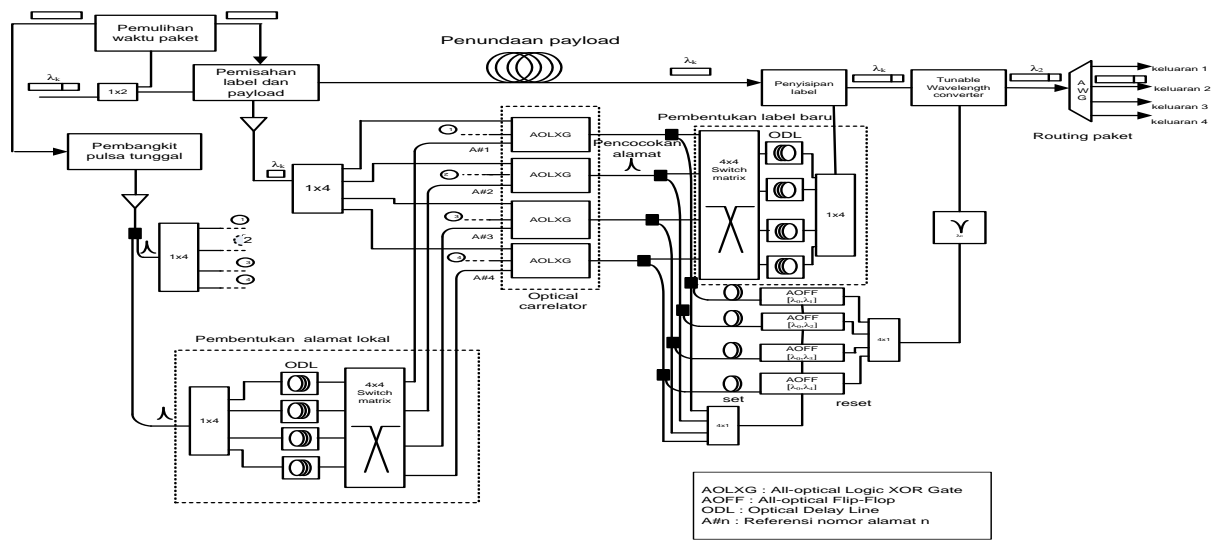

Gambar 21. LASAGNE label swapper dan router paket.

Paket kemudian dikirimkan melalui domain optik, dan hanya mungkin diubah arrayed waveguide grating (AWG), oleh ke dalam panjang gelombang.

karena itu panjang gelombang dimana paket meninggalkan blok AOLS menentukan port mana yang akan dilalui paket untuk meninggalkan node. Dua switch menyediakan fleksibilitas untuk mengatur tugas antara label yang datang dan label yang keluar serta panjang gelombang. Ukuran dari router paket (untuk contoh, jumlah dari optical correlator dan flip-flop) sangat bergantung pada jumlah dari alamat lokal yang digunakan pada routing table.

STOLAS, merupakan konsep AOLS yang menggunakan skema orthogonal labeling. Seperti yang ditunjukan pada gambar 22, paket dari metro/access network dikirimkan kepada metro/core network melalui edge router. Berdasarkan informasi pada header paket, edge router menentukan jalur labelswitched yang akan dilalui paket di dalam jaringan, dan memberikan label yang sesuai pada paket. Saat melintasi jaringan di dalam setiap node label akan diperiksa, diterjemahkan ke dalam label baru untuk menentukan jalur berikutnya yang akan dilalui paket. Label baru ini menggantikan label yang lama. Setelah mendapat label baru paket di-routing-kan ke jalur berikutnya. Pemrosesan label dilakukan pada kecepatan sedang di domain elektrik. Sedangkan payload data tetap dalam

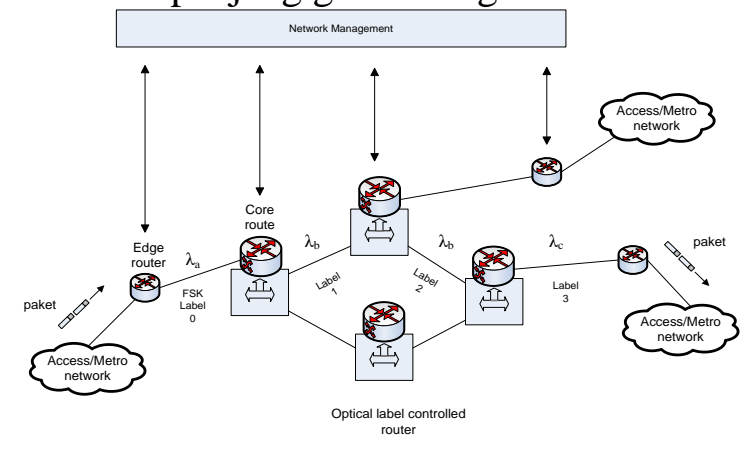

Gambar 22. Label swapping dalam paket IP melewati jaringan WDM.

Dalam STOLAS, informasi dari label dimodulasi secara orthogonal ke dalam payload data, dimana untuk data digunakan intensity modulation pada kanal panjang gelombang yang spesifik, sedangkan untuk label digunakan frequency atau phase modulation pada kanal yang sama seperti yang ditunjukan pada gambar 23 .

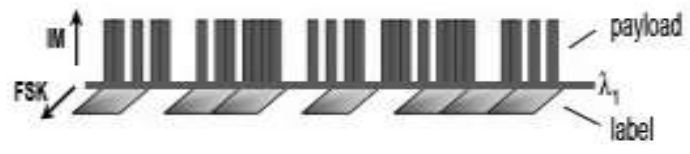

Gambar 23. Orthogonal packet labeling.

Rate payload data lebih besar dari rate label, contohnya 10 Gbps untuk payload data dan 155 Mbps untuk label. Karena modulasi secara orthogonal payload dan label pada dasarnya diposisikan pada dua kanal komunikasi yang berdiri sendiri atau 
independen. Namun demikian Frequency Shift Keying (FSK) modulation label membutuhkan sinyal non-zero payload untuk bisa agar dapat dimodulasi, sehingga akan mempengaruhi sensitivitas penerima payload. Menggunakan format modulasi orthogonal FSK untuk label dan payload data memberikan keuntungan yaitu label dan payload data dapat dengan mudah dipisahkan, dan label dapat dengan mudah ditukar tanpa mempengaruhi payload.

Seperti yang diperlihatkan pada gambar 24, edge router menyediakan orthogonal labeling yang didasarkan pada fast tunable laser dioda dimana panjang gelombang dapat diset dengan cepat untuk routing panjang gelombang, dan panjang gelombang ini juga bisa dimodulasi oleh FSK optik untuk menambah label. Label ini ditetapkan oleh label setting berdasarkan informasi header dari aggregate paket IP. Keluaran continous wave (CW) dari FSK modulation kemudian dimodulasi secara intensity oleh payload data dari paket IP.

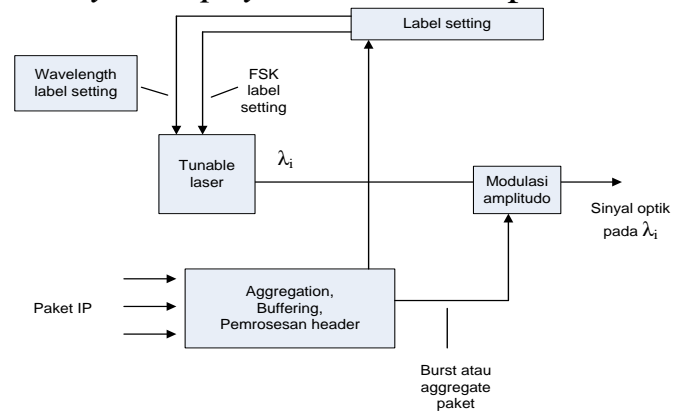

Gambar 24. Orthogonal labeling dalam edge router.

Swapping dari orthogonal FSK modulation label dilakukan pada core router seperti yang diilustrasikan pada gambar 25 , hal itu bisa dilakukan oleh Mach Zehnder Interferometer (MZI) menggunakan Semiconductor Optical Amplifier (SOA) pada kedua cabangnya. Sebagian kecil sinyal masukan diberikan kepada rangkaian pemrosesan label yang akan membaca label dan menggunakan look-up table untuk memperoleh label FSK yang baru, serta mengendalikan routing sesuai dengan yang dibutuhkan, dengan mengatur tunable laser pada panjang gelombang yang sesuai.

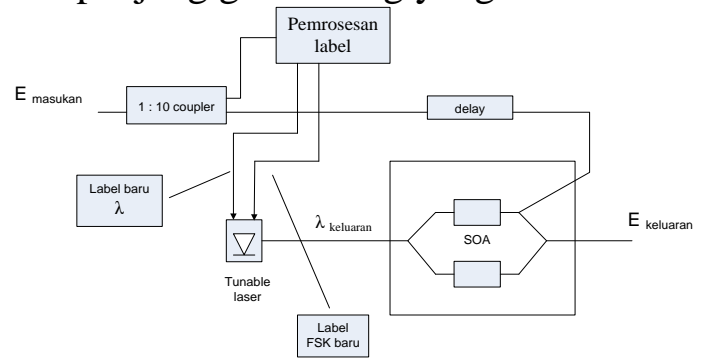

Gambar 25. Orthogonal optical label swapper.

Sebagian sinyal yang lain diberikan ke salah satu SOA, yang merubah shift phasenya sehingga menyebabkan MZI tidak seimbang. Oleh karena itu MZI akan melewatkan cahaya $\mathrm{CW}$ dari tunable laser dengan label FSK yang baru pada panjang gelombang yang baru juga. Perubahan phase SOA hanya dipengaruhi oleh intensitas dari cahaya yang dimasukan, bukan oleh phase atau frekuensi dari cahaya tersebut. Oleh karena itu hanya intensitas modulasi sinyal masukan yang dikirimkan dari panjang gelombang yang lama $\lambda_{\text {in }}$ ke panjang gelombang yang baru $\lambda_{\text {out, }}$ tetapi label FSK yang lama telah dihapus. Dengan demikian swapping label FSK dan konversi ke panjang gelombang yang baru dapat dicapai.

Dengan menggunakan rangkaian optical label swapper (OLS), modul label controlled optical router dapat dibangun seperti yang ditunjukan pada gambar 26 . Dalam OLS, label FSK ditukar dan panjang gelombang yang baru ditentukan. Routing sinyal dilakukan oleh Arryed Wavwguide Grating Router (AWGR) yang akan memandu sinyal port masukan ke port keluaran yang spesifik bergantung pada panjang gelombang dari sinyal masukan. Router pada gambar 26 memiliki 2 port masukan serat optik dan 2 port keluaran juga, serta tambahan 2 add port dan 2 drop part untuk adding atau dropping paket data lokal pada node. 


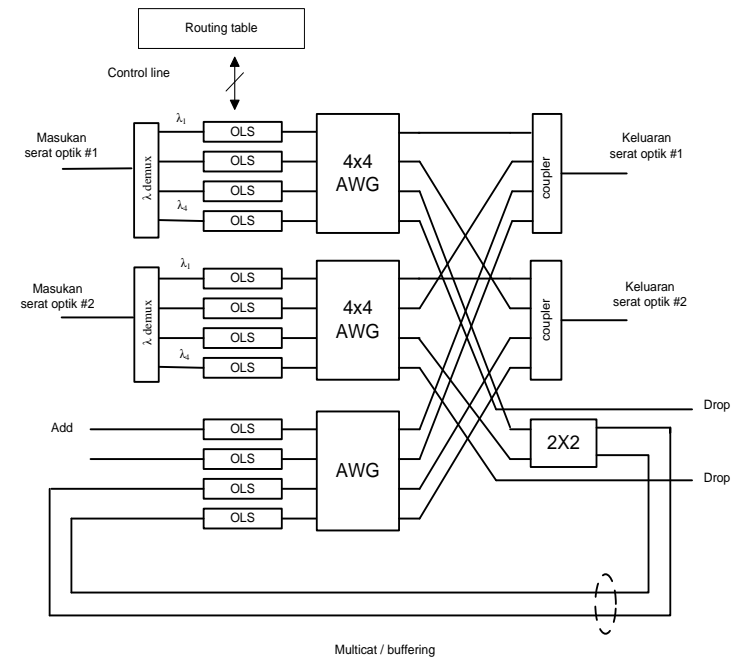

Gambar 26. Arsitektur node dasar STOLAS.

Tabel perbandingan antara AOLS dengan opaque

\begin{tabular}{|l|l|}
\hline \multicolumn{1}{|c|}{ Opaque } & \multicolumn{1}{|c|}{ AOLS } \\
\hline $\begin{array}{l}\text { Tidak menambahkan } \\
\text { label optik }\end{array}$ & $\begin{array}{l}\text { Menambahkan label } \\
\text { optik }\end{array}$ \\
\hline $\begin{array}{l}\text { Untuk proses routing, } \\
\text { opaque akan } \\
\text { memproses seluruh } \\
\text { paket }\end{array}$ & $\begin{array}{l}\text { Untuk proses routing, } \\
\text { AOLS hanya } \\
\text { memproses label optik }\end{array}$ \\
\hline $\begin{array}{l}\text { Pada proses routing, } \\
\text { paket berada dalam } \\
\text { domain elektrik }\end{array}$ & $\begin{array}{l}\text { Pada proses routing, } \\
\text { label dan payload } \\
\text { berada dalam domain } \\
\text { optik }\end{array}$ \\
\hline
\end{tabular}

Tabel perbandingan antara LASAGNE dengan STOLAS

\begin{tabular}{|l|l|}
\hline \multicolumn{1}{|c|}{ LASAGNE } & \multicolumn{1}{c|}{ STOLAS } \\
\hline Bit Serial label & Orthogonal label \\
\hline $\begin{array}{l}\text { Payload rate } 40 \mathrm{Gbps} \\
\text { dan label rate } 10 \mathrm{Gbps}\end{array}$ & $\begin{array}{l}\text { Payload rate 10 Gbps } \\
\text { dan label rate 155 } \\
\text { Mbps }\end{array}$ \\
\hline $\begin{array}{l}\text { Label swapping } \\
\text { menggunakan All } \\
\text { optical logic XOR gate } \\
\text { dan Optical Flip-Flop }\end{array}$ & $\begin{array}{l}\text { Label Swapping oleh } \\
\text { Mach Zehnder } \\
\text { Interferometer } \text { (MZI) } \\
\text { menggunakan } \\
\text { Semiconductor Optical } \\
\text { Amplifier (SOA) }\end{array}$ \\
\hline
\end{tabular}

E. Kesimpulan dan Saran

1. Paket IP melalui Gigabit Ethernet mempunyai overhead yang lebih sedikit dibandingkan melalui ATM pada paket IP sebesar 1500 byte.

2. Gigabit Ethernet lebih baik untuk pengembangan infrastruktur jaringan berbasis IP dibanding ATM.

3. Perbedaan terbesar dari jaringan opaque dan AOLS adalah pada penentuan proses routing. Pada jaringan opaque terjadi konversi O-E$\mathrm{O}$, sedangkan pada AOLS terjadi konversi O-O-O.

4. Jaringan AOLS hanya memproses label optik untuk menentukan routing selanjutnya dari paket.

5. Pada LASAGNE pemrosesan label optiknya dilakukan pada domain optik sedangkan pada STOLAS dalam domain elektrik.

6. Dengan infrasruktur yang ada di Indonesia, teknologi AOLS bisa diterapkan, tanpa harus mengganti seluruh infrastruktur yang telah ada.

\section{Daftar Pustaka}

[1]. Blumenthal, D.J. 2000. All-Optical Label Swapping Networks andTechnologies. Journal of Ligthwave Technology. Vol. 18. No. 12 December Tanggal 5 Desember 2005.

[2]. Blumenthal, D.J. 2002. All-Optical Label Swapping for the Future Internet, Optics \& Photonics News, America. Tanggal 18 Mei 2007.

[3]. Bakes, Catherine Murphy.,Chan M. Kim, Calvin T. Ramos. 2000. An Assessment of Gigabit Ethernet Technology and Its Applications at the NASA Glenn Research Center. NASA.

[4]. C. D., Cantrell. 2003. Transparent Optical Metropolitan-Area Networks. Photonic Technology and Engineering Center University of Texas at Dallas.

[5]. Ramos, F., E.Kehayas, J. M. Martinez, R. Clavero, J. Marti, L. Stampoulidis, 
D. Tsiokos, H. Avramopoulos, J. [7]. Gibson, D., Jerry. 2002. Zhang, P. V. Holm-Nielsen, N. Chi, P. Communication Handbook Second Jeppesen, N. Yan, I. Tafur Monroy.,A. Edition. CRC Press LLC. United M. J. Koonen, M. T. Hill, Y. Liu, H. J. States of America.

S. Dorren, R. Van Caenegem, D. [8]. Koonen, Ton., Idelfonso, Tafur Colle, M. Pickavet, B. Risopati. 2005. Monroy, J.J Vegas Olmos, Christophe IST-LASAGNE: Towards All-Optical Label Swapping Employing Optical Peucheret, Jean Jennen, Evi Zouganeli, Logic Gates and Optical Flip-Flops. Journal Of Lightwave Technology. Vol 23. No 10.

[6]. Garcia, Leon., Widjaja. Erik Van Breusegem, Geert Morthier, Jos van der Tol, Tommy Mullane, Kristian Blidegn, Peter Raaby. 2004. Optical Label Switched Networks-the 2000.Communication Network. McGraw-Hill Companies. United FP5-IST STOLAS project. BroadBand States. 